\title{
Wooden Inscriptions and the Culture of Writing in Sabi Paekche
}

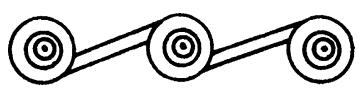

\author{
Marjorie BuRGE
}

\begin{abstract}
Surviving inscriptions from the Korean kingdom of Paekche 百濟 (ca. C.E. 250-660) are extremely few in number. Recent archaeological discoveries have uncovered an unprecedented cache of Paekche writing in the form of wooden tablets, known as mokkan 木簡, dateable to the period when the kingdom's capital was at Sabi 泗沘 (C.E. 538-660). This article first looks at the distribution of mokkan finds within the Sabi capital and argues that mokkan were one material surface utilized in the context of a multi-faceted written culture that included other media such as paper and stone. This article proposes that because wood was a relatively cheap, reusable, and disposable medium, mokkan became the material surface of choice for the acquisition of literacy and experimentation with Sinographic script. This meant that mokkan were not only a space for learning individual characters (calligraphic practice), but also for practicing composing sentences according to the rules of Sinitic syntax and in established Sinitic literary forms (composition practice). As a result, mokkan offer a unique window into the development of literary writing among Paekche elites during the late sixth and early seventh centuries. This article explores four examples of Paekche mokkan containing inscriptions that fall into the category of "composition practice," and argues that these compositions suggest literary form was an increasingly valued component of inscriptive practice in Paekche. KEYWORDS: mokkan, inscriptions, writing, literary composition, Paekche, Sabi.
\end{abstract}

\section{INTRODUCTION}

THE HistORY OF WRITING IN THE KOREAN KINGDOM of Paekche 百濟 (ca. C.E. 270-660) is known only in fragments, from secondary materials compiled in later eras and, increasingly, through archaeologically excavated inscriptions. ${ }^{1}$ While some writing seems to have been in use in the kingdom during the earliest era of its history, known as the Hansŏng 漢城 period (ca. C.E. 250-475), its scope was limited to ritual and possibly some state record-keeping purposes (Sin 2014). For the following Ungjin 熊川 period (C.E. 475-538), when the capital was located at modern Kongju 公州, at least some in the kingdom were sufficiently adept at written composition, as evidenced by the inscriptions found on two stones steles in the tomb of King Muryŏng (r. 501-523) 武寧王陵. However, sources for this period are also scarce, and the uses of writing were probably similarly limited (Kwŏn 2005; Pak C. 2015a, 2015b; Yi Chaehwan 2015). 
After the move of the capital to Sabi 泗沘 (modern Puyŏ 扶餘) in C.E. 538, the presence of inscriptions in the archaeological record expands considerably. Wooden tablets bearing ink inscriptions, known to scholars as mokkan 木簡, have been discovered at sites throughout the former capital as well as at some provincial outposts, including an iron production facility at Pogam-ni 伏岩里 in modern Naju 那州 (Kim S. 2009, 2010; Yi Chaech'ŏl 2015b; Yi Y. 2013), and the checkpoint at Paengnyŏng Fortress 栢嶺城 in modern Kŭmsan 錦山 (Kang 2009; Yi Chaech'ŏl 2015a). Despite the still relatively few sites that have yielded mokkan, discoveries span the entirety of the Sabi period (C.E. 538-660) and offer a window into the considerable diversity of script usage in this period of Paekche's history. Many of the inscriptions attest to a variety of administrative and record-keeping functions, while a significant number also suggest that script was used as a tool for learning and communication, as well as an outlet for experimentation and play.

In this article, I first outline the scope and character of the written culture of the capital at Sabi, focusing on questions of who was producing what sorts of texts, in what locations, and why. Then, through attention to some specific examples, I argue that within the context of the capital at Sabi during the sixth and seventh centuries, one learned to manipulate written language on mokkan and that the disposability and reusability of wood made mokkan the primary medium for one's entry and acculturation into the world of script. In this capacity, mokkan were certainly important for the refinement of one's calligraphy, but also served as a space in which one might hone one's ability to compose text in different forms. While scholars of mokkan have long categorized certain pieces as "writing practice," I propose that this category should be further broken down into "composition practice" and "calligraphic practice."

The examples I present in this article are best characterized as "composition practice." The prevalence of examples of composition practice among the still relatively small number of Paekche mokkan suggests that the ability to compose was valued at least as highly as the ability to produce legible inscriptions. As will be seen below, the honing of one's ability to compose could take many forms-from random jottings in metered prose, to Sinitic verse, to something resembling narrative-but in all cases, scribes are seen producing original texts that draw upon established Sinitic literary conventions. These inscriptions show that not only were scribes in Paekche aware of the greater Sintic literary universe but betray the growth of an increasingly formally aware written culture shared among Sabi's elites.

\section{BACKGROUND}

Mokkan are strips of wood carved for use as writing surfaces. Writing on wood has a long history in China, where bamboo was the preferred writing surface prior to the invention of paper during the Han dynasty. While bamboo and wood strips continued to be used alongside paper for some centuries thereafter, they had largely ceased to be in circulation by about the fifth century, supplanted by the increased availability of paper (Tsien [1962] 2004:96-99). In Korea and Japan, however, wood was an important medium for writing in the early stages of the assimilation of script technology (ca. sixth through eighth centuries). Because paper for some time remained a scarce commodity, it made good economic and practical sense to fell locally abundant trees and shape them into surfaces suitable for writing. 
As in China, the importance of mokkan as writing surfaces is thought to have diminished as paper became increasingly available in the Korean kingdoms and the Japanese archipelago (Yi K. 2013:24; Yun 2007a:71-74). ${ }^{2}$ While paper may not necessarily have been unobtainable, it was a more prestigious material, and its use imbued inscriptions with value (Frydman 2014:175; Lurie 2011:161-162). This is not to say that texts on mokkan were automatically devalued: mokkan were sturdier than paper and thus could be called upon for specialized tasks (Frydman 2014:175; Lurie 2011:162). However, while there are exceptions, generally it can be understood that mokkan operated in more mundane and preliminary contexts, providing support for the production of inscriptions of greater significance. ${ }^{3}$

The term mokkan was coined in Japan, where large numbers of inscribed wooden tablets have been unearthed consistently since $1961 .^{4}$ To date, approximately 380,000 mokkan have been recovered archaeologically from sites throughout the archipelago, with large concentrations found in the Yamato region (present-day Nara prefecture), where Japan's early historic capitals were located (Watanabe 2014:11). ${ }^{5}$ These inscribed artifacts have proved a boon to the study of Japan's early history, providing insight into aspects of early transportation networks, taxation systems, bureaucratic structure, folk rituals, educational processes, and poetic practices. Mokkan studies has become a full-fledged sub-discipline in the study of Japanese historical documents (Jap. shiryogaku 史料学), and a scholarly society devoted to the study of mokkan from the archipelago, formed in 1979, continues to meet and publish a journal on an annual basis. Japanese mokkan have also garnered the attention of scholars working outside of Japan (e.g., Farris 1998; Frydman 2014; Lurie 2011).

By contrast, scholars have just begun to tap the potential of Korean mokkan for the study of the Three Kingdoms (ca. C.E. 250-668) and Unified Silla (C.E. 668-935) periods, so until recently, very little has been published on Korean mokkan in English (Lee 2012, 2013, 2014, 2016). This is at least partly because mokkan from sites on the Korean peninsula remain considerably fewer than their Japanese counterparts, with, according to this author's calculations, only about 350 decipherable mokkan recovered from the territory of Paekche's peninsular neighbor, Silla 新羅 (ca. C.E. 250-935) and a little less than one hundred from Paekche sites. ${ }^{6}$ Mokkan were first discovered on the Korean peninsula in 1975 at Anapchi Pond 雁鴨池 in Kyŏngju 慶州, the former Silla capital. While this initial cache of about fifty mokkan opened up a new avenue for understanding written life in early historic Korea, research on them remained relatively underdeveloped until the use of infrared photography began in the early $2000 \mathrm{~s}$ (Hong K. 2013:96-98).

The discovery in 1983 of some five mokkan from Kwanbung-ni 官北里, a Paekche site in Puyŏ, went largely unremarked at the time. However, the unearthing of a single mokkan from the Kungnamji Pond 宮南池 site in 1995 and then more than 30 from the Nŭngsan-ni 陵山里 temple site over the course of several excavations from 1999 through 2002 attracted widespread scholarly interest to Paekche mokkan (Hong S. 2013:16). Since the early 2000s, a number of excavations at sites throughout Puyŏ have continued to yield mokkan, usually in small numbers. From the city of Puyŏ, a total of 80 mokkan have been unearthed and deciphered. As a result, a new corpus of written material from Paekche has been made accessible for research. 


\section{MOKKAN IN THE SABI CAPITAL}

The exact layout of Sabi when it served as Paekche's capital is still poorly understood. According to Samguk sagi 三國史記, Sabi seems to have been a candidate for the capital's transfer as early as the reign of King Tongsŏng 東城王 (r. 479-501), who went on hunting expeditions there (Best 2006:310; Kim K. 2005:102). An earthen wall (known as Nasŏng 羅城) eventually demarcated the northern and eastern boundaries of Sabi; it was either under construction or possibly even complete by the time King Sŏng 聖王 (r. 523-554) moved his court there in C.E. 538 (Kim K. 2005:102). It is clear that the location was chosen for strategic defense purposes, since the Kŭm River 錦川 marks its western border, while a large marsh extends to the south. Because of the concern with defense, the fortress on the low peak of Mount Puso 扶蘇山 in the north, along with the Kwanbung-ni area at its foot, had long been considered the likely site of the royal palace.

More recent scholarship has placed the palatial complex in the Kwanbung-ni foothills and parts of the adjacent Kua-ri 舊衙里 district, with Mount Puso as a defensive and garden space (Pak S. 2010:264-265). Yi Pyŏngho (2013:71) goes a step further in arguing that, based on artifact distribution and the strategic locations of facilities established by the Tang military force that occupied Sabi after Paekche's defeat in 660, the palace may have included the entirety of the Kwanbung-ni, Ssangbung-ni 雙北里, and the northern part of the Kua-ri districts.

Some support for Yi's theory of the palace's location might be found in the distribution of mokkan finds in Puyŏ. To date, no mokkan have been recovered from the interior of the fortress at Mount Puso. However, a total of twenty-five mokkan have been unearthed from eight different sites in an area to the south and east of Mount Puso known as Ssangbung-ni. Yi Pyŏngho (2013) identifies this area as an eastern administrative extension of the palace; the content of the mokkan found in this area generally supports this idea. Meanwhile, the Kwanbung-ni site also falls within the area Yi designates as the royal palatial complex (Yi identifies this particular area as the the residence of the royal family). Overlaying Yi Pyŏngho's theory for the location of the palatial complex onto the distribution of mokkan finds in Puyŏ shows significant overlap (Fig. 1).

Based on Figure 1, five of the eight Ssangbung-ni sites fall within or immediately to the north of what Yi calls the "eastern administrative area" (B). He speculates that this eastern administrative extension was added to the palace after a flood in 612 damaged parts of the original palatial complex. ${ }^{7}$ Indeed, all eight of the sites that yielded mokkan in this area seem to date to the early-mid seventh century (Yi P. 2013:117,127). Yi does not identify the area to the immediate east of Mount Puso Fortress-encompassing the Twitkae, Ssangbung-ni 280-5, and Ssangbung-ni 328-2 sites-as being connected to the palace. However, given the trajectory of the outer fortress wall (i.e., Nasŏng), it is certainly possible that these sites were proximate to, if not immediately within, the sway of officialdom.

In addition, other mokkan sites not immediately falling within the palace boundary nevertheless seem to have had a royal connection. These include the complex at Kungnamji Pond, at the southern edge of the capital, which was built and presumably used primarily by the royal house, and the temple at Nŭngsan-ni, located adjacent a royal cemetery just outside the outer fortress wall, which was founded by and probably remained under the control of the royal family. ${ }^{8}$ This leaves only the 


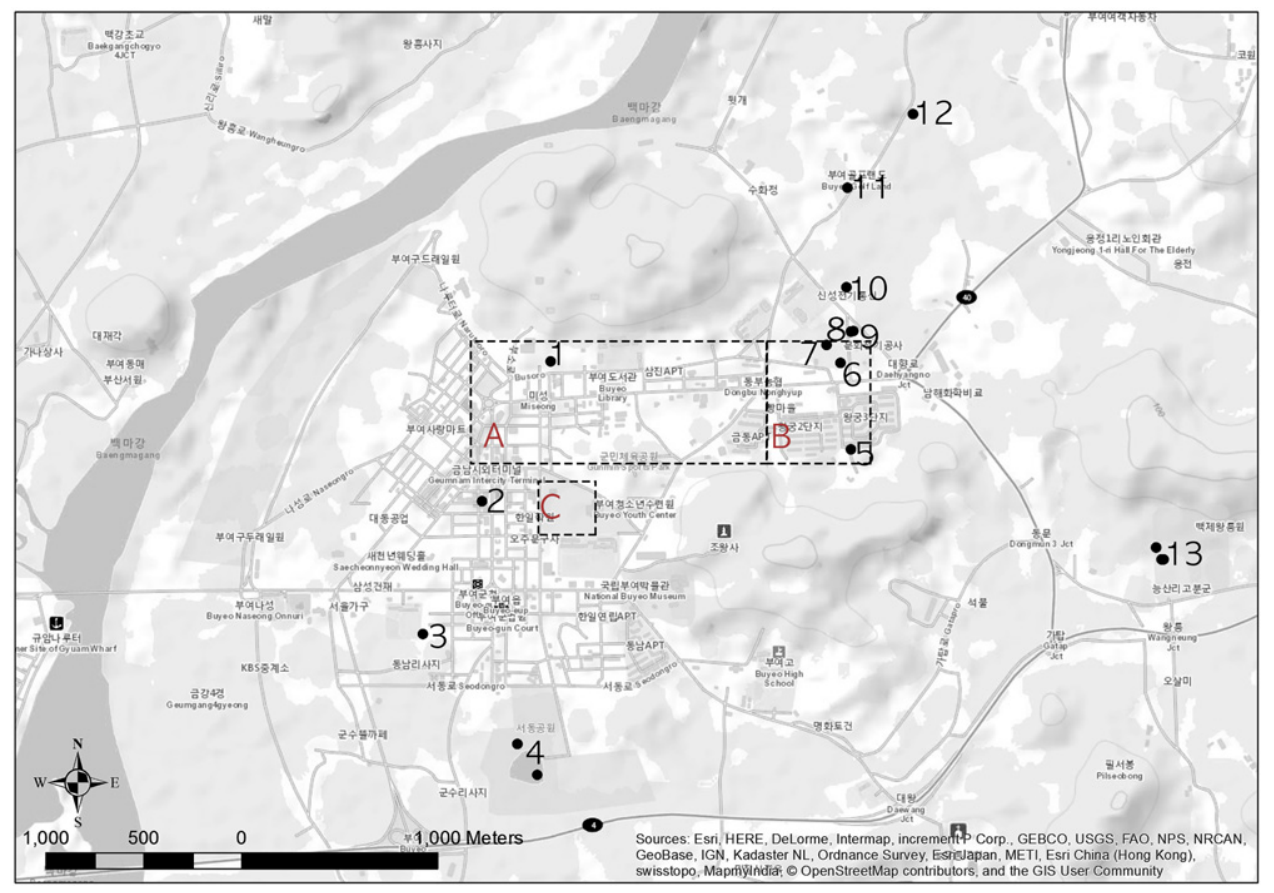

Fig. 1. Mokkan sites in Puyŏ, with dashed lines showing Yi Pyŏngho's proposed palatial complex (A), its eastern extension (B), and the temple Chŏngnimsa (C). Mokkan sites are: (1) Kwanbung-ni; (2) Kuari 319/Puyŏ Holiness Church; (3) Tongnam-ni 216-17; (4) Kungnamji; (5) Ssangbung-ni 102; (6) Ssangbung-ni 201-4; (7) Ssangbung-ni Hyŏnnaedŭl Site; (8) Ssangbung-ni 173-8/Sabi 119; (9) Ssangbung-ni 184-11; (10) Ssangbung-ni 280-5; (11) Ssangbung-ni 328-2; (12) Ssangbung-ni Twitkae; (13) Nŭngsan-ni Temple. ${ }^{9}$

Tongnam-ni 東南里 216-17 (located near the site of the ruined temple at Tongnamni) and Kua-ri 319 (part of a private estate) sites as possibly without direct connection to the palace or the bureaucratic state.

The location of the final deposition of a mokkan is not the only factor in understanding its inscription and use-life as an object. However, the distribution of finds within Sabi, with such a large number coming from the Ssangbung-ni administrative complex or from within Yi's proposed palatial boundaries, suggests that overall mokkan were used as writing surfaces by officials within the state bureaucracy more than anyone else. However, as will be seen below, the writings of these officials were not always "official" in nature. Furthermore, mokkan are also found in limited numbers outside of "official" areas, and so cannot always be assumed to function in an "official" capacity.

\section{TYPES OF MOKKAN FROM SABI}

In both Korean and Japanese scholarship, mokkan are generally sorted into the standard categories of "Document," "Tag," and "Other." Documents are both records and pieces of official bureaucratic discourse. Tags identify the contents of a shipment and would normally have been attached to the shipment; as a result, they have a typical 
Table i. Mokkan Classifications for all Sites in Present-day Puyŏ

\begin{tabular}{lcccc}
\hline SITE & DOCUMENTS & TAGS & OTHER & UNKNOWN \\
\hline Ssangbung-ni 102 & 0 & 1 & 0 & 1 \\
Ssangbung-ni Hyŏnnaedŭl & 1 & 3 & 1 & 2 \\
Ssangbung-ni 280-5 & 1 & 1 & 1 & 0 \\
Ssangbung-ni 173-8 (Sabi 119) & 1 & 2 & 0 & 2 \\
Ssangbung-ni Twitkae & 0 & 0 & 1 & 1 \\
Ssangbung-ni 184-11 & 0 & 1 & 0 & 0 \\
Ssangbung-ni 201-4 & 2 & 0 & 0 & 0 \\
Ssangbung-ni 328-2 & 0 & 2 & 1 & 0 \\
Kwanbung-ni & 3 & 2 & 0 & 3 \\
Kungnamji Pond & 1 & 0 & 2 & 0 \\
Nŭngsan-ni Temple site & 3 & 4 & 11 & 17 \\
Tongnam-ni 216-17 & 0 & 0 & 0 & 1 \\
Kua-ri 319 & 2 & 2 & 1 & 3 \\
Total (80) & 14 & 18 & 18 & 30 \\
\hline
\end{tabular}

rectangular shape modified with v-shaped grooves carved out of the right and left sides at either the top or bottom to facilitate attachment with rope or string. "Other" is a catch-all category for any mokkan that are neither Documents nor Tags, but can be assigned a function, such as those used for writing practice, ritual purposes, doodling, or transcribing poetry. Any mokkan that cannot be categorized are considered "Unknown."

Table 1 outlines types of mokkan found at sites within modern Puyŏ. The majority of Paekche mokkan fail to fit within the standard categories of Document or Tag, and are thus considered either "Other" or "Unknown." However, some interesting trends can be observed within specific sites and among the sites that make up the Ssangbungni site group. Of the twenty-five artifacts recovered from the eight Ssangbung-ni sites, five can be conclusively classified as Documents, while ten are Tag mokkan. Of the remaining ten mokkan, two appear to be examples of writing practice, one is a central rod for a scroll, one is a study aide featuring multiplication tables, and six are of an unknown nature. While five may seem like a small number for "official" Documents, only 14 out of the 80 total mokkan from Puyŏ can be put conclusively into this category (Table 1). Meanwhile, those that can be classified as Tags are also few-18 out of 80 total mokkan - and 10 of these are from sites in the Ssangbung-ni group.

Based on the data in Table 1, those mokkan from the Sssangbung-ni site group classified as either Documents or Tags make up 60 percent of all mokkan from these sites, while only 24 percent fall into the "Unknown" category. Meanwhile, for Puyŏ as a whole, only 40 percent can be conclusively classified as Document or Tag, while 37.5 percent of mokkan are classified as Unknown. For non-Ssangbung-ni sites only, the percentage of combined Documents and Tags goes down to roughly 30 percent, while Unknowns climb to 44 percent.

These figures might be partly explained through an understanding of how Paekche's written culture may have been divided among media. While there are many possible reasons for the significantly fewer numbers of mokkan found in Korea 
compared to Japan, poor preservation and possibly different waste management strategies cannot account entirely for the gap. Mokkan do not seem to have ever been mass-produced in either Paekche or Silla in the same way that they were in eighth century Japan. Yi Kyŏngsŏp (2013:20-21) notes that each Korean mokkan seems to have been an individual piece, with minimal effort expended on manufacture. Further, it appears unlikely that several mokkan would ever have been tied together for the purpose of inscribing longer texts; rather, multi-surfaced mokkan (Kor. tagangmyŏn mokkan 多角面木簡, referred to as $g u$ 解 in Chinese contexts) were used when more space was needed (Yi K. 2013:21-24; Yun 2007a:73).

Given Paekche's close relationship with the Liang court during much of the sixth century, and sustained relationships with the Sui and Tang thereafter, it is possible that paper was not as scarce there as it might have been in Japan's early historic capitals. It is also possible that paper was being manufactured in Paekche. Unfortunately, there is little empirical evidence for the availability of paper in the Sabi capital, but based on the relative paucity of surviving mokkan, and the relatively low numbers of "official" Document mokkan compared to those of a more inscrutable nature, it seems probable that paper served as a more prominent surface for inscription in Paekche, while the role of mokkan was relatively restricted.

The high prevalence of mokkan used for writing practice suggests that the role of mokkan as a material surface for writing in Paekche was somewhat specific. Among the 80 mokkan from Puyŏ, 14 are classified as "writing practice," constituting 17.5 percent of total mokkan (equivalent in number to Document mokkan). In fact, given that what appear to be Document mokkan may also contain some "writing practice," as in the example of the Chiyaga Meal Rice Record mokkan discussed below, many of those pieces that have been identified as Documents might be better classified as "document drafts." While it may not always be possible to distinguish a draft from a final version of a document, there are some strikingly draft-like qualities in the examples described below. I argue these qualities are substantial enough to re-categorize these mokkan as "composition practice." Although it is not impossible that some drafts would have been composed on paper, I aim to show that one of the fundamental roles of mokkan in the written culture of Sabi was as a surface for drafting.

\section{MOKKAN AS SURFACES FOR COMPOSITION}

Writing on mokkan was necessarily ephemeral. Whatever was important would be presumably copied onto paper, while what was not important could be simply discarded either by scraping the text off the surface so the wood could be reused or discarding the entire piece. In this regard, mokkan mirror the wax tablets of Europe's Middle Ages. The very ease with which inscriptions could be erased from wax made wax tablets an ideal surfaces for "poetic invention and composition" and the jotting down of "ideas and fragments of texts filed away in memory" (Chartier 2007:4-5, 24). I here examine four examples of mokkan inscriptions that I think exhibit the productive possibilities inherent in a disposable writing surface.

Note that I do not see legibility as a significant issue for interpreting the examples presented here, although there are other Paekche mokkan for which it is a more prominent problem. While there are some issues with legibility for the specific mokkan discussed in this article, infrared photography has allowed for fairly definitive readings to be produced for all four of them. Where disagreements or uncertainties remain, a 
character is rendered as $\square$. Other symbols used in the following transcriptions include: $\bigcirc=$ blank space; $/ /=$ transition from one large column to two columns of writing; / = transition between two columns of writing of the same size; and 【】 = text in reverse orientation to that written on other sides. ${ }^{10}$ For the sake of simplicity, I have transcribed the modern Sino-Korean pronunciations of characters in standard McCune Reischauer Romanization. ${ }^{11}$ Unless otherwise noted, all translations into English and interpretations of the textual content of mokkan are my own, presented with acknowledgement that there may be a range of other possibilities.

\section{Nüngsan-ni Temple Site Mokkan No. 8-1, the "Chiyaga Meal Rice Record” 支藥兒食米記}

Mokkan No. 8-1 from the Nŭngsan-ni temple site is an example of a "writing rod" (Ch. gu 解) or a "multi-surfaced mokkan" (Kor. tagangmyŏn mokkan) (Fig. 2). "Multisurfaced mokkan" are often touted as unique to peninsular mokkan culture, being almost unknown in Japanese contexts (Yi K. 2013:21-24; Yun 2007a:71-74). There are precedents in Chinese contexts, however. During the Han dynasty, $g u$ were used as surfaces for the copying out of texts by students, as well as for the transmission of official state documents in a durable form (Yun 2007a:70-71). Yun Sŏnt'ae (2007a) argues that the peninsula's contact with Chinese mokkan culture beginning in the Han Commanderies period (108 B.C.E.-C.E. 313) accounts for their unique prevalence in sixth century Paekche and Silla contexts. However, it should be noted that the "peak" in the use of multi-surfaced mokkan on the peninsula comes long after their prominence during the Han dynasty (Yun 2007a:73). Of the 17 multi-surfaced mokkan found at Sabi capital sites, 14 are from the Nŭngsan-ni temple site, and are therefore dated to sometime in the mid-late sixth century; the other three are datable to the early seventh century. The Chiyaga Meal Rice Record mokkan, found during the eighth stage of excavations at the Nŭngsan-ni temple site in 2002, is one of the sixth-century examples. It is the longest Paekche mokkan recovered to date, measuring $440 \mathrm{~mm} \times 20 \mathrm{~mm} \times 20 \mathrm{~mm}$.

The Han'guk mokkan chajŏn [Character Dictionary of Korean mokkan] deciphers the inscription as follows (modified from Munhwajaech'ŏng and Kungnip 2011:262):

Side 1: 支藥兒食米記 初日食米四斗 $\bigcirc$ 二日食米四斗小升一 $\bigcirc 三$ 三食米四斗

Side 2: 五日食米三斗大升 六 日食三斗大二 七日食三斗大升二八日食米四斗大

Side 3: 食道使家 $\square \square$ 次如逢//使猪 / 小治//耳其身者如黒也 $\square$ 道使後後弾耶 方//牟氏 / 牟祋// 袂耶

Side 4:【又十二石 $\square$ 又一二石 $\square$ 又十四石 $\square$ 十二石 $\square$ 又石又 $\bigcirc$ 二石 $\square$ 又二石】

Side 1: Chiyaga Meal Rice Record. First day, meal rice four mal; second day, meal rice four mal one small toe $e^{12}$ third day, meal rice four $\mathrm{mal}^{13}$

Side 2: Fifth day, meal rice three mal one large toe; sixth day, meal three mal two large, seventh day, meal three mal two large toe, eighth day meal rice four mal large

Side 3: Meal tosa's house ${ }^{14} \square$ ch'a, Yŏbong, the Sori Chŏi, all of their bodies are as if black. After the tosa of rear T'anya-bang, Mo Ssi, Mo Tae, Taeya ${ }^{15}$

Side 4: Another twelve sŏm, another one two sŏm, another fourteen sŏm, twelve sŏm, another sŏm another, two sŏm, another two sŏm

While it is unclear just who or what 'chiyaga 支藥兒' refers to, at least the first two sides of this mokkan can be readily understood as an account register, likely recording 


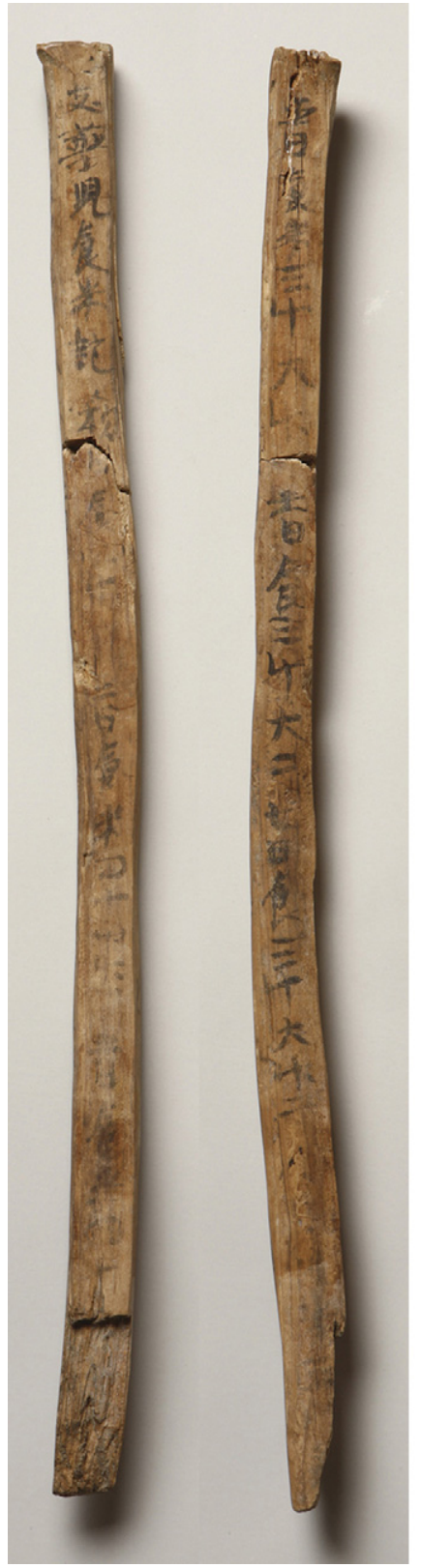



Fig. 2. Nŭngsan-ni Temple Site Mokkan No. 8-1, "[Chiyaga] Meal Rice Record 支 藥兒食米記”: Side 1 (far left); Side 2 (middle left); Side 3 (middle right); Side 4 (far right). (Courtesy of Buyeo National Museum.)

the provision of "meal rice" either to or by that entity. ${ }^{16}$ This mokkan was recovered from a natural waste water channel in the northwestern part of the site that was not in use until after construction of the temple began in 567 (Yi Chaehwan 2014:160; Yi P. 2008:71). Its deposit sometime after the temple was inaugurated suggests that the mokkan is somehow connected to the operation of the temple or checkpoint facilities located nearby. ${ }^{17}$ Unfortunately, little else can be discerned as to the nature of 'chiyaga 

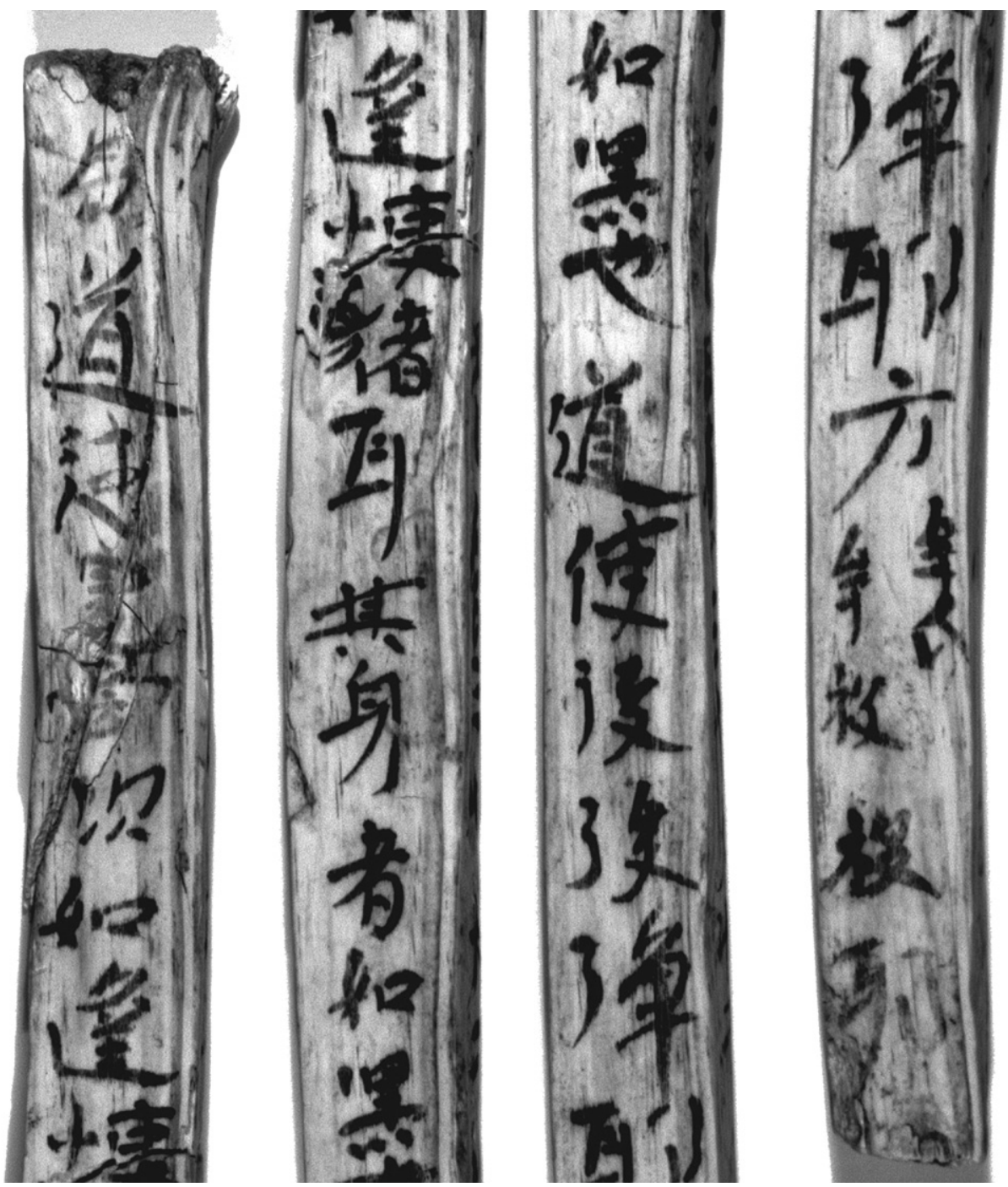

Fig. 3. Close-up infrared photos of Side 3 of Nŭngsan-ni Temple Site Mokkan No. 8-1, segmented into four sections. (Courtesy of Buyeo National Museum.)

支藥兒' from the archaeological or material record. Nevertheless, the text on the first two sides of this mokkan is easily digested without a clear identification of this entity.

The nature of the text on the third and fourth sides is less clear, however. There is an abrupt change in the format of the text on the third side, which seems to have been written in a different hand, with a thinner tipped brush and darker ink than the other three sides (Fig. 3). While the fourth side seems to feature simple writing practice with its repetition of numerals and the unit 石 $(s o m)$, the third side cannot be immediately identified as a calligraphic exercise or in association with the text on sides 1 and 2 .

Some scholars have tried to somehow connect the enigmatic text on the third side with the inscriptions on the first two sides (e.g., Son 2010). ${ }^{18}$ However, most 
acknowledge that there seems to be something of a break between the main text of the "Chiyaga Meal Rice Record" (sides 1-2) and the text on the remaining two sides (cf. Kondō 2008; Yun 2007a, 2007b). ${ }^{19}$ Yi Pyŏngho (2008) offers what would appear to be the simplest explanation for the disconnect: Side 3 was partially erased. Yi (2008) observes that the first character on the third side, 'sik 食' [eat; meal], seems to be in a lighter shade of ink and is spaced at a distance and to the upper right of the next character, 'to 道' (Fig. 3, far left, first character from top). On this basis, Yi argues that this 'sik 食' is in fact an incompletely erased trace of a previous inscription. Yi further suggests that the two characters identified as the sequence 'soch' $i$ 小治', which appear alongside the sequence 'sajo 使猪', also appear to be traces of a previously erased text (Fig. 3, middle left, second and third characters from top, left side). In this case, the style of 'so 小' resembles the 'so 小' seen in the sequence 'sosŭng 小升' on the first face. This all suggests that the third face of the mokkan had been a continuation of the account register found on the first two surfaces, but the original text was scraped off, albeit incompletely, to allow for a new inscription (Yi P. 2008:78-79).

The new inscription on Side 3 confounds standard classifications in that it features grammatically complete sentences, a relative rarity for mokkan. The spatial parameters of most mokkan called for brevity and therefore their inscriptions usually contain only essential information, mostly nouns (as seen on sides 1 and 2 of this mokkan). Yi Pyŏngho (2008:82-83) suggests that the same person inscribed all three sides, with the first two sides offering an objective account of provisions meant for consumption by others, while the third side is a subjective self-memo intended to help the scribe recall identifying characteristics of certain individuals of the rank tosa 道使. Some similarities in calligraphic style between Side 3 and Sides 1 and 2 may indicate that the inscriptions are by the same person. However, given that $\mathrm{Yi}$ argues this mokkan shows signs of erasure and re-inscription, it is equally possible to imagine the third side as the work of a separate individual. Furthermore, if the content of the third side is nothing more than a few notes about the physical appearance of certain tosa, meant to facilitate the scribe's own recall of said individuals, why does it feature complete sentences?

The recovery of wood shavings (Kor. pusŭrŏgi) from the Nŭngsan-ni temple site shows that erasure and reuse of mokkan was indeed occurring in Paekche; further, the reuse of parts of mokkan that had formerly functioned as Documents or Tags for calligraphic practice was not uncommon. The fourth side of this mokkan is one such example. The repetition of numerals and the '石' (š̆m) character, the omission of important practical information such as dates (which figure prominently on sides 1 and 2 , the main text of the record), and the fact that the inscription is written upside-down when compared to the other three sides are all features marking this side as calligraphic practice. Because there is no clear evidence of erasure on this side, it may be that the remaining unused space on the fourth side of the mokkan was adopted for the purpose of this writing exercise. However, Side 3 of the "Chiyaga Meal Rice Record" mokkan shows that parts of a mokkan might also be reused for "jotting," or what I argue is more aptly referred to as "composition practice."

Yi Pyŏngho (2008:82-83) argues that this third side exhibits a subjective point-ofview inflected with the scribe's own self-awareness. He sees this self-awareness in the act of taking down a "self memo," as essentially opening up a dialogue between self in present and self in future. The idea that the text of Side 3 is a "memo" of sorts does not preclude its identification as "composition practice." While our scribe may have 
indeed been interested in storing information about certain tosa for later recall, a close examination of the inscription suggests he was also clearly attentive to the form in which he did so. The text on this face can be broken down into several smaller segments. As noted above, Yi Pyŏngho (2008) has argued that this mokkan shows signs of erasure and reuse. Yi does not mention in this context the two graphs that come between the first 'tosa 道使' and the character 'ch'a 次,' which the Han'guk mokkan chajŏn identifies as ' $k a$ 家 $\square$ ' (Fig. 3, far left, fourth and fifth characters from top). Like the other characters that seem to have been "erased," these characters are in a considerably lighter shade of ink and are partially obscured by a natural feature of the wood that may have hindered erasure or re-inscription. Given that the inscription on this side was in all likelihood for the scribe's eyes only, it is possible that these were simply left as-is from this face's previous use. In addition, tosa 道使 as written at the top (Fig. 3, far left, second and third characters from top) looks to be in a considerably less practiced hand than when it appears again below (Fig. 3, middle right, fourth and fifth characters from top); while they were probably written by the same person, the shade of the ink and the thickness of the brush strokes suggest they were perhaps written at different times, with different implements, and with differing degrees of precision. We might accordingly set aside the first five characters in the inscription on Side 3 as either pieces of a previous inscription or as isolated moments of calligraphic practice.

It is then possible to begin with 'ch'a 次' (Fig. 3, far left, sixth character from top), whose placement after the laceration in the wood and inscription in a deeper shade of ink suggests the beginning of a new inscription. While 'ch'a 次' has normally been interpreted as part of a person's name (as are the following 'yŏbong 如逢' and 'chŏ $i$ 猪 耳,' with 'sori 小吏' being understood as a title), it is also possible to understand its function as an adverb beginning a new sentence. ${ }^{20}$ This allows for the parsing of the following twelve characters of the text into two six-character segments, each ending with a sentence final particle: ' $i$ 耳' (Fig. 3, middle left, fourth character from top) and 'ya 也' (Fig. 3, middle right, third character from top). While these are by no means a poetic parallel couplet, they do show that our scribe was tuning his content to fit a particular form: “次如逢使猪耳 其身者如黒也 [Thereupon it was just as if meeting a boar messenger. His body was as if black]."

As noted above, the text that comes before 'ch'a 次' seems to be the product of a separate inscriptive moment, while what follows ' $y a$ 也' is yet another blank space, almost the length of a full character, before the second 'tosa 道使' appears. Visually, these two sentences are set off as a pair. Even the space between them is mediated by the final stroke of the character ' $i$ 耳,' which dangles almost to the top of ' $k i$ 其' (Fig. 3, middle left, fourth and fifth characters from top). These two sentences are also written in characters slightly narrower than those found toward the bottom of the mokkan, which fill the width of the surface. All of this would seem to mark these two sentences as a separate and distinct inscription from the remaining text on this face.

Without any further context, these isolated sentences read as nonsense. Their nonsensical quality might be construed as another indication that this was composition practice; while the scribe has devoted considerable attention to form, his content seems relatively inconsequential, bordering on playful. This inscription appears to be a work in progress, inscribed on a surface that had once featured a relatively mundane record, and which might have later featured some other sort of text, should another moment have called for this particular inscription's erasure. 
The inscription on this mokkan has survived to be studied by scholars in the present entirely by accident. Its current status as a piece of cultural history does not mean we should disregard the possibility that it represents a moment of "drafting" or preliminary composition. This interpretation of the purpose of the text becomes all the more likely as we continue down the third face, where the text that follows the twelve characters just described returns to simple calligraphic practice of place and personal names (Fig. 3, beginning with fourth character from top of middle right, ending bottom far right). The act of turning briefly to experiment with sentence form, for the purpose of both practice and entertainment, is perhaps a natural outgrowth of a material environment (the wood surface) that encouraged the pursuit of refinement in calligraphic form.

\section{Nŭngsan-ni Mokkan No. 305, “Song of Karmic Bonds from a Previous Life” 宿世歌}

At Nŭngsan-ni, a temple adjacent a royal cemetery stood immediately outside what was presumably the eastern gate of the city, where officials would have closely monitored traffic going in and out of the royal capital. At this site, people composed a variety of texts, including records of meal provisions such as the "Chiyaga Meal Rice Record" mokkan, ritual texts for the performance of road-side rites (Nŭngsan-ni Mokkan No. 295), and instructions for the performance of official duties (Nŭngsan-ni Mokkan No. 301) (Kungnip and Kungnip 2009). There is no shortage of examples of calligraphic practice on mokkan from this site, and, as in the case of Side 3 of the "Chiyaga Meal Rice Record" mokkan, calligraphic exercises might have provoked composition practice.

In addition to such efforts, full drafts of works of poetry and prose can also be found among the corpus of Paekche mokkan, which suggest that scribes were operating within a larger written culture that valued formal sophistication as well as calligraphic mastery. One of the earliest examples of such "drafts" is the inscription on the twosided Nŭngsan-ni Mokkan No. 305, known as the "Song of Karmic Bonds from a Previous Life" (modified from Munhwajaech'ŏng and Kungnip 2011:260) (Fig. 4):

Side 1: 宿世結業同生一處是 / 非相問上拜白来

Side 2: 慧量 $\bigcirc$ 師 $\square$ （藏? )

Side 1:

宿世結業 In a previous life, our karma became intertwined

同生一處 And in this life, we are once again together-

是非相問 So let us ask each other what is right and wrong

上拜白來 Bowing before you, I come to humbly plead. ${ }^{21}$

Side 2: Hyehun [of] master's repository

Kim Younguk (2003:140-144) was the first to argue that the text on this mokkan could be segmented into a verse consisting of four four-character lines. Since then, it has been generally accepted by scholars that this inscription is a work of "Paekche poetry," although there is some disagreement over interpretation (cf. Cho H. 2006; Kim Youngsim 2009; Yi S. 2008). Because of the paucity of surviving material from Paekche, literary historians have been eager to ascribe this verse "canonical" status as a work of Paekche literature (Cho T. 2005, vol. 1:133-134).

While the text on this mokkan is certainly remarkable, the push to canonization elides sufficient consideration of the material context. The text was composed on a 

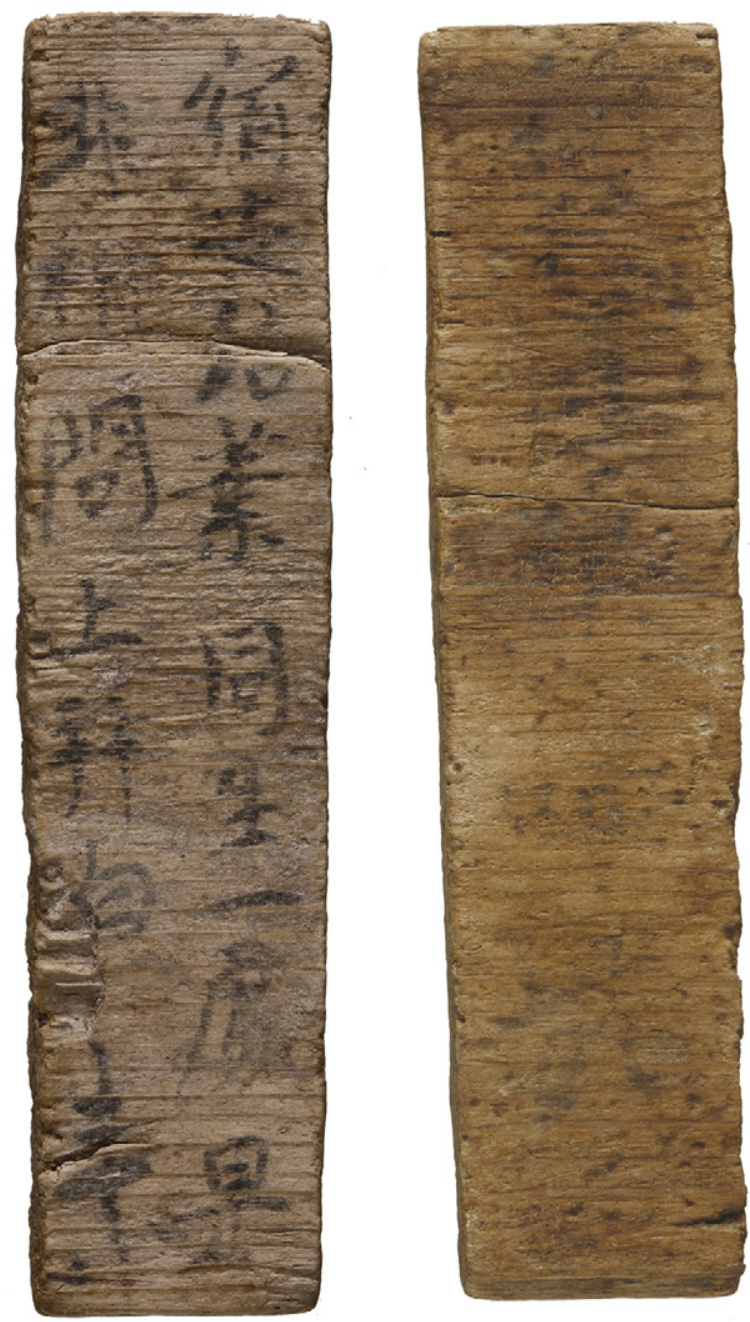

Fig. 4. Nŭngsan-ni Temple Site Mokkan No. 305: Side 1 (left); Side 2 (right). (Courtesy of Buyeo National Museum.)

mokkan, and as such shares material form with a number of preliminary texts, including raw records to be later compiled in final form, calligraphic or composition practice, and drafts of documents. Even if this was its final form, and assuming it circulated beyond its composer, the fact that this verse was inscribed on a mokkan likely communicated something of its relative importance to those who came in contact with it. Furthermore, this mokkan features the name of a Buddhist priest, was found at the site of a prominent temple, and its inscription features Buddhist-inflected terms such as 'sukse 宿世' [“previous life”], “kyŏrŏp 結業' [“intertwined karma”], and 'tongsaeng ilch'ŏ 同生一處' [“this life, same place”]. The solemn humility expressed in the fourth line suggests an exchange between someone of lower rank with someone of higher status, and therefore a specific social interaction. The language of this line would not be out of place in an official request document, and despite the verse form of its inscription, this mokkan may have functioned as a document exchanged 
within the temple hierarchy, a material index of the forging of an important social bond.

None of these factors make this verse any less literary, but they do necessitate reflection on its ability to accurately represent "Paekche literature." The syntax appears to be more or less standard Sinitic, with the possible exception of the fourth line. While Kim Yŏnguk (2003) argues it is composed in Paekche idu 吏讀, Cho Haesuk (2006)'s interpretation of it as a Paekche verse "translated" into Sinitic is probably more accurate. ${ }^{22}$ Translation would surely have been one fundamental component of the production of any sort of inscription in this period. Taking the additional step of fitting a translated text into a pre-existing Sinitic literary form (four-character verse) suggests an awareness of the process of composition beyond mere mechanics. The calligraphy on this mokkan is generally neat and there seem to be about half-character-sized spaces left open between each four-character "line," emphasizing the intentional nature of the metered form of the inscription and suggesting a desire for an appealing presentation. However, the arrangement of characters is not especially precise, with nine in the right column and seven in the left. The sizes of the characters in the left column vary considerably from top to bottom, with the final character seemingly written without as much concern for legibility. In addition, possibly due to natural features in the wood, there is an especially large gap left open between the final two characters, 'paek 白' and 'rae 來.' While these imperfections do not necessarily mean the object itself was not exchanged, it could suggest this was a draft.

Another peculiar feature of this mokkan is its shape: it is a short, relatively wide rectangular shape with remarkable thickness, measuring $128 \mathrm{~mm} \times 31 \mathrm{~mm} \times 12 \mathrm{~mm}$. The only similar example found thus far is an eighth century Silla mokkan-Anapchi Mokkan No. 206, excavated from Anapchi Pond in Kyŏngju-which also features what appears to be metered text (Fig. 5). This piece measures $145 \mathrm{~mm} \times 42 \mathrm{~mm}$ $\times 10 \mathrm{~mm}$, and includes two columns of six and five characters, respectively, on front and back. While the first column on the first side starts out in a relatively neat and even regular script, the second column seems squeezed in as an afterthought. On the back, the calligraphy begins to look more like cursive or "grass" script. While these are only two examples, a comparison of these physically similar mokkan, both featuring metered text, suggests that a certain type of mokkan may have been utilized for the drafting of verse. Outside of these two, no other similarly shaped mokkan have yet been identified, however. Based on the manner in which the style and spacing of the text deteriorate toward the end of the inscription in both examples, it nevertheless seems likely that both inscriptions are drafts. Initial drafting was likely an important step in composing poetry; that such drafting may have occurred on a disposable surface such as a mokkan is an important possibility to consider.

Among early historic Japanese mokkan are a sub-category of approximately forty pieces known as uta mokkan 歌木簡 or "poetry mokkan;" these contain verses or fragments of verse in the vernacular. None of these bear particular resemblance to Nŭngsan-ni Mokkan No. 305 or Anapchi Mokkan No. 206. Moreover, they seem to have largely been used in performative or ritual contexts or are examples of calligraphic practice (Frydman 2014; Sakaehara 2011). While it is possible that the Paekche and Silla examples cited here may have functioned in performative or ritual contexts, this would probably have taken a quite different shape from the hypothesized use of uta mokkan. Unlike Japanese uta mokkan, which Sakaehara Towao (2011) hypothesizes to have been about three times the length (around $360 \mathrm{~mm}$, or two shaku 尺) and contain 

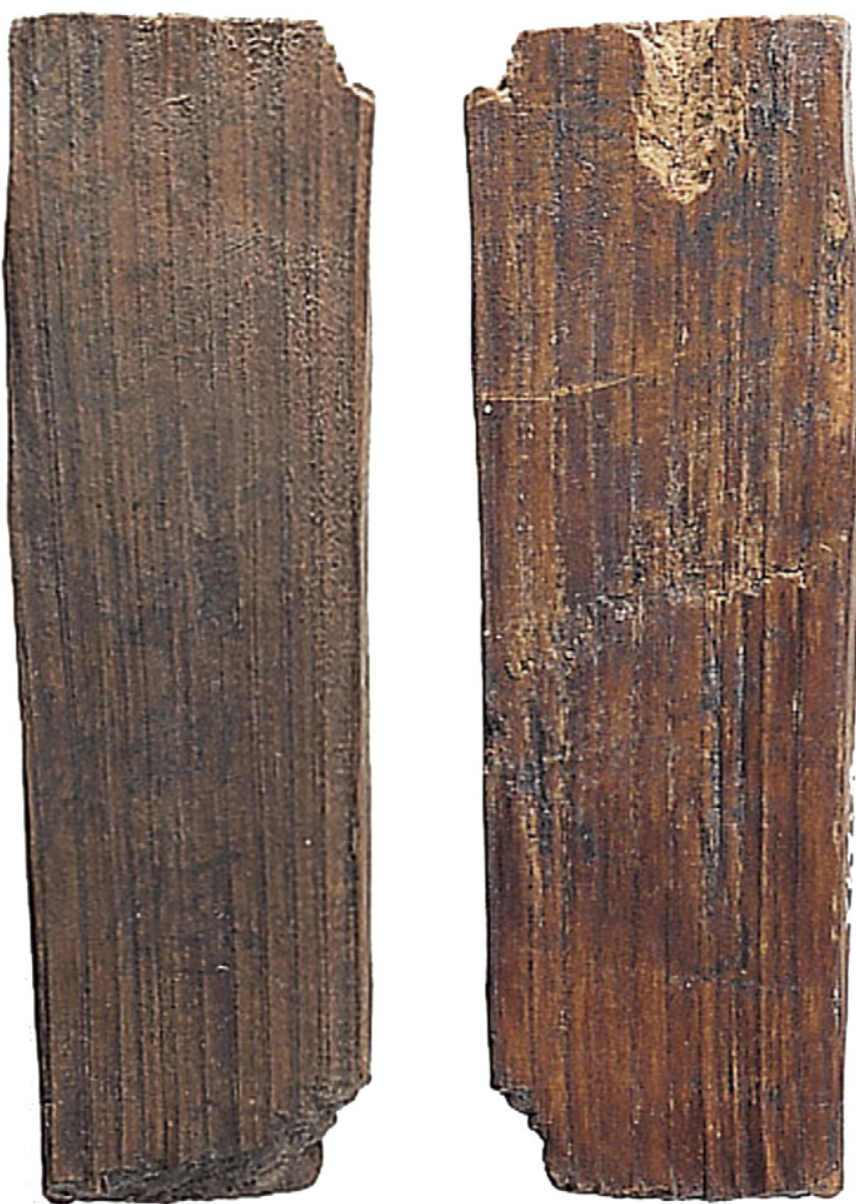

Fig. 5. Anapchi Pond Mokkan No. 206. (Courtesy of Gyeongju National Museum.)

text largely composed in phonograms, these two mokkan are quite compact and written in nearly pure Sinitic (or possibly a form of semantogram-centric transcription of the vernacular, per Kim Yŏnguk 2003). These features make it hard to imagine they could have been of much use to an oral performer of verse.

The composition on Nŭngsan-ni Mokkan No. 305, dubbed "Song of Karmic Bonds from a Previous Life" (Suksega 宿世歌), is likely either a piece of correspondence or a draft of a verse, but was probably not circulated as "literature" on a mokkan or used as an aid in oral performance. While there seems to have been some effort expended on presentation in terms of both literary and calligraphic form, other features of the inscription also suggest this was not the final incarnation of this particular inscription. Its language is certainly more poetic than the "nonsense" sentences of Side 3 of the "Chiyaga Meal Rice Record," but given the way in which the verse positions its speaker vis-à-vis its addressee, it seems probable that a more polished version was later produced, possibly on a different material, to be offered to the intended recipient. Nevertheless, this mokkan is another example of an inscription from the Nŭngsan-ni site where content has been molded to fit an existing literary form. 

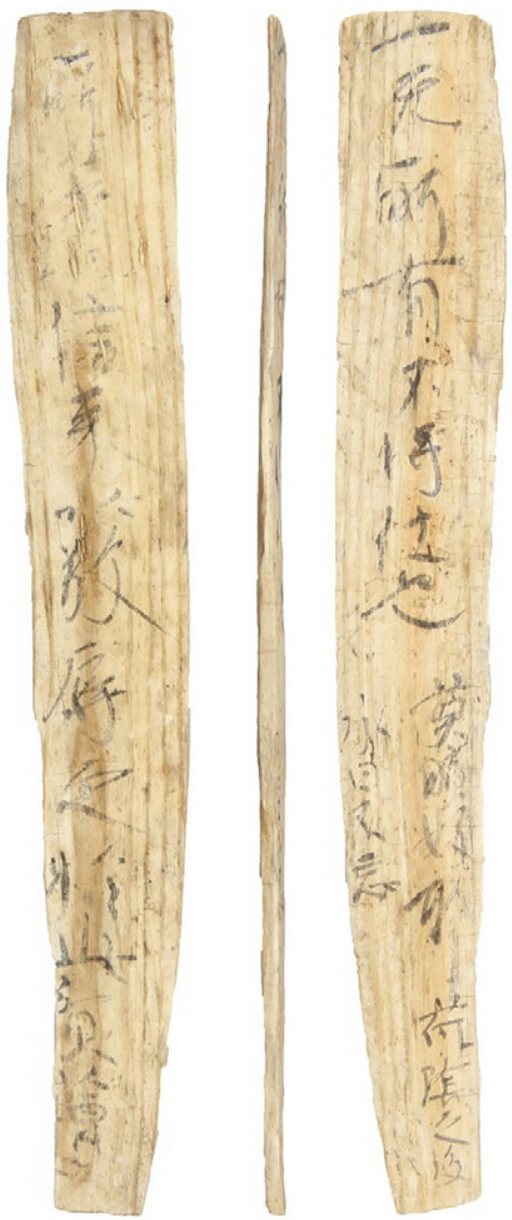

Fig. 6. Kua-ri Mokkan No. 47: Side 1 (left); Side 2 (right). (Courtesy of Buyeo National Museum.)

Kua-ri Mokkan No. 47

Most of the mokkan unearthed at the Nŭngsan-ni temple site date to the late sixth century. While excavations have not yet uncovered any contemporaneous examples from within the city walls, early and mid seventh century sites in the Ssangbung-ni and Kua-ri districts have yielded a number of mokkan that show similar trends in attention to literary form. Kua-ri Mokkan No. 47, recovered from the Puyŏ Central Holiness Church site in the Kua-ri district of present-day downtown Puyŏ, contains a trace of epistolary culture (Fig. 6). Although it appears to be a complete composition, it seems no more likely that this would have been its final form than the verse inscribed on Nŭngsan-ni Mokkan No. 305.

The inscription on the mokkan reads as follows (Sim and Kim 2015:54):

Side 1: 所遣信來以敬辱之於此貧薄

Side 2: 一无所有不得仕也//莫瞋好邪荷陰之後 / 永日不忘

Side 1: The letter you sent came, and I felt both veneration and shame [upon reading it]. [That you should send it to me] even though I am poor and insignificant. 
Side 2: with not one thing to my name, and having been unable to attain rank. - I shall no longer be enraged by matters of good and bad: now, after all the blessings you have granted me, for all my days I will be unable to forget.

This inscription is strikingly legible and written in an obviously practiced hand. Furthermore, our scribe writes in four-character lines that show considerable familiarity with epistolary convention and commands sophisticated expressions such as 'kyonngyok 敬辱, (“veneration and shame”), 'pinbak 貧薄” (“poor and insignificant”), and 'haŭm 荷陰' (“time of blessings”) (Sim and Kim 2015:58-59). Moreover, after meeting all the requirements of epistolary discourse, the scribe appends a three-line addendum that focuses on his personal feelings of gratitude toward the addressee. Whether this portion is written in smaller characters intentionally or because the scribe ran out of space, it shifts focus to the writer's feelings in a way that distinguishes these three lines from the first five, such that the smaller text produces an echo-like post-script.

This mokkan was found in an area designated Feature \#5, an oblong marsh-like feature about eleven meters long by four meters wide, at least part of which may have been an outhouse (the eggs of human parasites have been found within the feature) (Sim et al. 2012:51). While the mokkan was found mostly intact, its discovery in this particular feature strongly suggests it was intentionally disposed. Furthermore, Sim Sangyuk and Kim Yorngmun (2015) note that the content shows none of the information that would be normally appended to the beginning or end of a letter, such as the date and names and titles of the sender and recipient. It does include an initial greeting, but few other of the formal elements of a letter are present. In other words, the mokkan contains only the main text of the letter. While Sim and Kim (2015) admit that this seems strange, they still assume the mokkan itself was exchanged as a letter. What they do not seem to consider is that this mokkan contains only those portions of a letter that might need to have been drafted in advance. The sender needed to spend some time crafting his sentences, and he did so on a mokkan.

The Kua-ri site is located near the center of the Sabi capital, just outside the area that Yi Pyŏngho (2013) argues was the location of the palatial complex. The features uncovered at the site are largely related to water management, which has led to the theory that this was the site of the garden of a private estate (Sim et al. 2011:121). If so, the resident, living in close proximity to the palatial complex, was almost certainly a high-ranking official. However, it is not clear who composed the text on the mokkan or if it was originally composed anywhere near where it was deposited. Nevertheless, its presence here suggests that the reach of the script in which it was written extended beyond the immediate boundaries of the bureaucracy. Further, its content suggests that written composition had become an important aspect of elite social interaction and that concern with proper literary form had become a crucial element of decorum. As a result, it is possible that drafting one's correspondence ahead of time on a disposable surface such as a mokkan was common practice.

\section{Kungnamji Mokkan No. II-2}

Verses and letters were not the only compositions being drafted on mokkan in Sabi. Kungnamji Mokkan No. II-2 features an inscription that shares many of the draft-like features seen on Nŭngsan-ni Temple Site Mokkan No. 305 and Kua-ri Mokkan No. 47, while echoing some of the more "playful" qualities of Nŭngsan-ni Mokkan No. 8-1. Its inscription has been deciphered by Ki Kyŏngnyang (2014:136) as follows (Fig. 7) ${ }^{23}$ : 
Side 1: $\square$ 君前軍曰今 $\square[$ [敵? ] 白惰之心 $\square \square[$ 之? ] $\square$

Side 2: 死所可依故背 $\square$ 作弓豰 $\square[$ [日？]間 $\square[$ 落? ]

Side 1: $\square$ lord before, Kun said, now (enemies?) have revealed their ignorant hearts, . . . Side 2: Death is what can be depended upon. Thereupon, turning his back . . . made a bow and drew it, the (sun?) at that time (set?) . .

This mokkan emerged largely intact from an irrigation channel excavated on the northwest side of Kungnamji pond. Upon discovery, this mokkan was originally classified as a wooden object because no ink was visible to the naked eye; however, during the conservation process, an inscription was revealed and subsequently deciphered (Ki Kyŏngnyang 2014:135; Kim C. 2001:428). Initially, it was widely thought that the inscription must be based on a classical text of some sort, but no such text could be identified. Furthermore, the mokkan was deliberately split at the top, probably as part of a deposition process. Kim Chaehong (2001:429, 431-432) argues that the intent to destroy the mokkan probably indicates it is not a mere transcription of

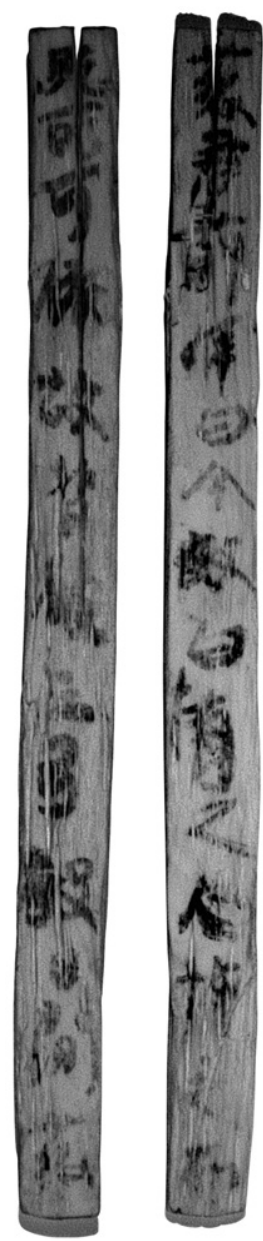

Fig. 7. Infrared photo of Kungnamji Mokkan No. II-2:

Side 2 (left); Side 1 (right). (Courtesy of Buyeo National Museum.) 
an extant work. Ki Kyŏngnyang (2014:143) outlines an alternative interpretation of the text, arguing that it recounts the meritorious actions of a military leader, so perhaps was part of an evaluative process whereby rewards were granted for esteemed service.

While Ki's understanding has some appeal, the idea that this is an official document of some kind finds little support, as it fails to mention any specific dates or personages. While the first character is illegible and may be the name of the 'kun 君' ("lord”), it is unlikely - with the possible exception of a well-known personage or a member of the royal family - that an individual would be identified by surname only. Meanwhile, the character ‘軍' (romanized as 'Kun' in the above translation) does appear to be a name, but again it is a single character, and so barring some additional narrative context that could have been provided elsewhere (perhaps on another mokkan), it would not appear to refer to a historical individual. Even if this mokkan did fulfill the sort of function that Ki suggests, it goes beyond what would have been necessary for such a task in narrating a vivid scene complete with dialogue.

The brush strokes here are thick and uneven, while the spacing of each character is relatively consistent and careful, with a few exceptions. While fourteen characters fill the space on the front, only thirteen occupy the back. For the most part the characters fill the width of the mokkan, with the exception of ' $i$ 日' on the second side, which appears to have been deliberately written narrowly, perhaps in order to distinguish it from 'wal 曰' on the front. While Kim Chaehong (2001) doubts whether there is a connection between the two sides, it would seem that narratively they do somewhat fit together, and the calligraphic style is consistent between them.

The mokkan features the recounting of a speech made by an individual, seemingly named 'Kun 軍,' before a certain lord (“kun君'). Kun expresses resentment toward unnamed "enemies" and an intent to effect their deaths. Although there are some illegible characters on the bottom of the first side, I believe the quotation initiated by ' $w a l$ 曰' carries over to the second side, ending after ' $\breve{u} i$ 依,' where there is a rather large space left open before the following character, ' $k o$ 故.' There, the language shifts to describing actions, which seems to be prompted by the end of the speech. 'Pae 背' can be taken as a verb indicating to "turn one's back," but the following character is considered to be indecipherable. However, the faint outline of the right side radical appears to be 'kan 艮,' while the left radical resembles a standing heart radical, which makes this character possibly 'han 恨,' an identification that would certainly befit the context. Ki's identification of the following character as 'chak 作' is somewhat suspect, as there appears to be no person radical ( 1 ) to the left of 'sa 怎'; moreover, 'sa 年' arguably fits the context better, as an adverb which modifies the action that follows. In the case of the sequence 'kunggu 弓殸', however, Ki's identification is quite convincing. Even though the left side of ' $k u$ 豰' has been blotted over with ink, the outline of the 'kung 弓' radical remains recognizable. It should be noted, however, that this sequence diverges from standard Sinitic word order in putting the direct object, ‘kung 弓’, before the verb, ' $k u$ 嗀'. The following 'ilgannak 日間落' provides a temporal context, while zooming out in order to end the scene. A more polished translation might look like this:

Side 1: $\square$ 君前軍曰今敵白惰之心 $\square \square \square$

Side 2: 死所可依 $\bigcirc$ 故背恨 $\square$ 乍弓豰日間落

Side 1: Before Lord $\square$, Kun said, "Now our enemies have revealed their ignorant hearts ...

Side 2: They can depend on death." Thereupon he turned his back, and resentfully, swiftly drew back his bow. The sun, at that moment, set. 
The inclusion of some rather obscure characters such as ' $k u$ 豰' here suggests that this inscription is more than calligraphic practice, and would be more aptly described as composition practice. Mokkan featuring calligraphic practice generally exhibit the repetition of certain characters or sequences of characters and such practice is usually geared toward those graphs that might be considered more useful in drafting official documents or correspondence. There is no repetition in this inscription; rather, the author has deliberately chosen characters that seemed most appropriate for conveying the content. Words such as 'han 恨' ["resentfully"] work to portray the protagonist Kun's (軍) state of mind, while adverbs such as 'sa 乍' [“swiftly”] serve as a bridge between Kun's emotions and actions. Kun speaks directly here, characterizing his enemy as "ignorant" [ $t a$ 惰] in no uncertain terms, then declaring his own intentions and taking swift action. There is no real meter or rhyme at play here: the power of the text's form is dependent on the deliberate and evocative word choices. However, with the thick brush strokes obscuring certain characters, this text hardly seems to have been composed to be easily read and understood by others. In fact, the attempt to dispose of it might suggest a desire to actively conceal it. Therefore, it is perhaps best understood as an example of "composition practice," where the writer was experimenting with crafting a written narrative. In this case, the author may not have been particularly interested in conforming to any given Sinitic literary style, but the text clearly evokes the potential of individual Sinitic words.

\section{CONCLUDING REMARKS}

Sites where mokkan have been recovered in Puyŏ are a small fraction (14\%) of the total number of excavated sites with Paekche period features. ${ }^{24}$ Meanwhile, a much larger number of sites have yielded ink stones, some of considerable quality (Kim C. 2001:425). This suggests that while the culture of writing in Sabi included mokkan, it was not constituted solely of them: mokkan filled a particular niche, namely for drafting, practicing, and experimenting with written language. Paper and stone would have also filled particular niches, with paper being the most precious and stone the most permanent surfaces for inscription. Mokkan made sense as a medium for disposable, preliminary, and provisional writing, but people would have turned to other materials when seeking something durable, sharable, or otherwise suitable for a "final" text.

If we understand mokkan as having this specific role in the culture of writing at Sabi, those that have survived can offer us an intriguing, yet necessarily only fragmentary, picture of the emergence of literary writing in Paekche. While I have only cited four examples in this article, all four represent moments in which individuals were making thoughtful inscriptive choices based on their understandings of the expressive possibilities of the Sinitic script. These examples indicate that by the Sabi period elites in Paekche were not only concerned with content, but with form, and that they actively practiced composition in addition to calligraphy. In their compositions, these elites exhibit an awareness of their medium that can only be characterized as a feature of a self-conscious written culture.

\section{ACKNOWLEDGEMENTS}

I would like to thank the Korea Foundation and the Kyujanggak International Center for Korean Studies for their support of this research. I would also like to thank the Buyeo National Museum and the Gyeongju National Museum for their permission to use the 
mokkan images. I would like to extend special thanks to Professor Lee SeungJae of Seoul National University for his guidance and support.

\section{NOTES}

1. When I refer to writing in Paekche, I am speaking of Sinographic (Chinese character) script, which probably first became known to individuals on the Korean peninsula through contact with the Lelang 楽浪 commandery (108 B.C.E.-C.E. 313), an outpost of the Han dynasty (and later under the control of the Wei 魏 [C.E. 220-265] and Jin 晋 [C.E. 265-420]). There is currently no evidence that any other kind of writing was used on the Korean peninsula during the Three Kingdoms or Unified Silla periods.

2. Based on current evidence, mokkan use arguably diminishes on the peninsula post-seventh century; however, mokkan use peaks during the eighth century in Japan. Yun Sont'ae (2007a:73) speculates that the reason mokkan continued to be used in large numbers in Japan alongside paper was not merely economic (i.e., that paper was harder to obtain/more expensive in Japan), but because mokkan seem to have been introduced to Japan (probably by individuals from Paekche) in the early part of the seventh century. Their use in Japan probably followed the example of the Korean kingdoms at that time, where mokkan and paper were used side by side in different capacities.

3. Lurie (2011:153, 162), writing about early historic Japan, notes the importance of mokkan in providing the literal material support (i.e., facilitating the flow of writing supplies) for the production of Queen-Consort Kōmyō's 光明皇后 copy of the Yue Yi lun 楽毅論, preserved in the Shōooin 正倉院 (dated 744). As an important material surface for literacy acquisition (and the practice of calligraphy and composition) mokkan also arguably supported the functioning of written culture as a whole.

4. Fortuitously, the word mokkan is a Sinitic compound with the same pronunciation in Korean as in Japanese.

5. This figure includes mokkan from later periods. Early historic mokkan make up approximately 250,000 of these.

6. The two kingdoms of Paekche and Silla were in close proximity in the southern part of the peninsula, but they remained culturally distinct, retaining different foreign ties and regularly clashing with each other militarily until Paekche's final defeat by the combined forces of Silla and Tang China in 660. Linguistically, they both spoke southern Han languages that were probably closely related (Yi S. 2017:421), perhaps enough to be mutually intelligible, but their histories of the reception of literacy are quite distinct.

7. The relevant passage from the Paekche Annals of Samguk sagi is as follows: " $13^{\text {th }}$ year [612], $5^{\text {th }}$ month. A flood inundated and destroyed houses of the populace" (Best 2006:356).

8. It should be noted that the current reconstructed Kungnamji does not accurately represent its scope or location during the Sabi period, although there is some overlap. Kungnamji Mokkan No. II-2 (discussed in this article) was found in an irrigation channel on the northwest side of the pond, meaning it may not have originated from the royal complex itself, but from some sort of facility in close proximity (Ki Kyŏngnyang 2014:135; Kim Chaehong 2001:428).

9. The map in Figure 1 was created using $\operatorname{ArcGIS}^{\mathbb{B}}$ software by Esri. $\operatorname{ArcGIS}^{\circledR}$ and $\operatorname{ArcMap}^{\mathrm{TM}}$ are the intellectual property of Esri and are used herein under license. Copyright () Esri. All rights reserved. For information about Esri ${ }^{\circledR}$ software, visit www.esri.com.

10. This code is based on that used by the Japanese mokkan research society Mokkan Gakkai 木簡学会 and in the database of Japanese mokkan managed by the Nara National Institute for Cultural Properties 奈 良文化財研究所. I have adopted these notations because standard markings have yet to be developed within Korean scholarship.

11. Progress on reconstructing the phonetic qualities of the Paekche language and Sino-Paekche sounds for Chinese characters is as yet insufficient to be reflected in my Romanizations. I look forward to a future moment when Sino-Paekche Romanizations may be possible.

12. One toe is a measurement for grain, traditionally $1 / 10$ of a mal (斗) and 1/100 of a sŏm (石). It is unknown if these relative values are accurate for Paekche. In Korea, one mal is the equivalent of ten toe, about 18 liters; sŏm (石) is the largest measurement unit for grains, traditionally the equivalent of ten mal, one hundred toe, or 180 liters. The appearance of "large toe" 大升 and "small toe" 小升 here further complicates matters, though this distinction is not found on other inscriptions that can be similarly dated, so is largely a matter of speculation (Yi S. 2017:127). Kondō Kōichi (2004:99) understands 小升 as it appears on Han Juyan Tablets 居延漢簡 as equivalent to 1/3 of a 斗 (Ch. dŏu). Yun Sónt'ae (2007a:137-139) argues that the 大 升 and 小升 that appear on the mokkan discussed here cannot be equated with the 大半升 and 少半升 of the Han texts analyzed by Kondō and suggests that they more likely represented an efficient shorthand for representing a "one person portion" (小升) and "two person portion" (大升). According to Yi Yonghyŏn (2007:280-281), one "large toe 大升" was less than or equivalent to 1/3 of a mal, or 31/3 toe, while a "small toe 小升" was simply a way of distinguishing a normal toe from a "large toe." 
13. The readings mal, toe, and sŏm are based on traditional renderings of these characters into Korean (as attested in Middle Korean). In the case of mal, this reading is also supported by part of the inscription on Nŭngsan-ni Mokkan No. 306, which has been deciphered as “斗之末米, [tu, this is mal (rice)] (the character 米 [rice] is actually written smaller and to the bottom right of 末, likely meant to be an annotation, indicating perhaps that $t u=m a l$ is the case "for rice"). This inscription appears to give a phonogram-based reading of the character 斗 as 末 (mal, or $\star_{\text {mat }}$ ), with 之 seeming to function as either a genitive or appositive particle (this would be something akin to 'tu in mal [mal, which is tu]' or 'tu ŭi mal [tu, that is, mal]' in modern Korean) (Yi S. 2017:125-126).

14. Tosa were officials dispatched from the center to administer territory in the provinces. See Kondō Köichi (2004:102). The term is attested in inscriptions from all three peninsular kingdoms (Koguryŏ [ca. first century C.E.-668 C.E.], Paekche, Silla).

15. For this translation, I have followed Yun Sŏnt'ae's (2007a:141) interpretation. I offer a different interpretation in the following discussion.

16. There are several theories with regard to the identity of the chiyaga 支藥兒 entity. Yun Sŏnt'ae $(2007 a: 136 ; 142-143)$ has proposed that 支藥兒 was the name of a position for those who were in charge of the provision of medicinal plants grown in the provinces, while Yi Pyongho (2008:78) argues that 支藥兒 was the name of a building or facility in charge of the distribution of rice or the storage of goods at the temple. Kondo Koichi (2008:344) argues that 支藥兒 is akin to the title 薬師 found on two of Silla King Chinhŭng's (r. 540-576) territorial tour steles and was likely someone responsible for distributing medicine to help stop the spread of disease. It is also possible to parse 支藥兒 as 支 + 藥兒, where 支 means “paid to" or “provided to," so the name of the entity would have been simply “藥兒.” Yi Yonghyŏn (2007) and Son Hwanil (2010) understand 支藥兒 in this way and interpret 支藥兒食米記 as a "record of meal rice provided to "Yaga 藥兒,",

17. This is significant insofar as it is a clear challenge to the notion advanced by Kondo Koichi (2004) that the Nŭngsan-ni mokkan pre-date the temple's construction/are related instead to the construction of the capital city wall (Nasŏng).

18. Son Hwanil (2010:241) reads the third side as providing something of narrative bridge between the provisions outlined on the first two sides to the following fourth side. He sees the first two sides as recording the provisions granted by some sort of central institution to 'Yaga' (藥兒), followed by a shift to describing a certain tosa named Mo Tae 牟袂 (on the third side), who then granted the additional provisions described on the fourth side. According to Son, it was at the home of the tosa Mo Tae that the scribe met a sori 小吏 who raised pigs and whose body was black (i.e., dirty).

19. Yun Sŏnt'ae (2007a:138-144) does not offer a convincing theory as to why the content changes so drastically on the third side, but he does seem to acknowledge that the third side is likely a different sort of document or record than that of the first and second sides. Yun (2007b:83-87) argues that the third and fourth sides are both distinct from the "meal rice record" written on the first through second sides, with the third side containing short memos about individuals who had come from the provinces (he sees the text as primarily consisting of a list of names with either ranks or place names, reflected in the initial translation above) and the fourth side being calligraphic practice. Kondo Kōichi (2008:345) does not attempt to explain the third side's function in relation to the other three sides, but argues that the text consists of the names and origins of officials from the provinces who had come to the facilities at Nŭngsan-ni (temple or checkpoint), about whom a certain scribe felt the need to jot down some notes.

20. The character 次 is attested in personal names of individuals of Paekche background in Buddhist inscriptions from the early Unified Silla period (Yun 2007a:139-140).

21. The formulation 上拝 literally means "bowing upward," but this is awkward in English. It also suggests the bow is being "offered up" to someone who is "above" the speaker, so I have translated it as "bowing before you" (i.e., "bowing in your presence").

22. Idu, as Kim Yŏnguk (2003) is using it, is an umbrella term to refer to methods of transcribing vernacular Korean language(s) using Sinographic characters. He argues this verse would have been read out loud (hundok) in the Paekche language.

23. I find Ki's (2014:137-143) identifications convincing and so have opted to follow his reading. Munhwajaech'ong and Kungnip's (2011) is similar, though not as complete, as Ki's:

\section{Side 1: $\square$ 君 $\square$ 軍曰今敉白有之心 $\square$ \\ Side 2: 死 $\square \square$ (所?)可依故背 $\square$ 三月 $\square$ 日間 $\square$}

24. This number is quite different if we restrict the search to Ssangbung-ni, where 35 percent of sites have yielded mokkan. These figures calculated based on information provided by the Paekche Kodo Munhwa Chaedan [Ancient Paekche Capital Cultural Foundation], through their Paekche Sabi tosŏng yujŏk chŏngbo sisŭt'em [Paekche Sabi capital archaeological sites information system] website, accessible at www.thesabi.co.kr. 


\section{REFERENCES CITED}

BEST, JONATHAN

2006 A History of the Early Korean Kingdom of Paekche, together with an annotated translation of the Paekche Annals of the Samguk sagi. Cambridge, MA: Harvard University Asia Center.

Chartier, Roger

2007 Inscription and Erasure: Literature and Written Culture from the Eleventh to the Eighteenth Century, trans. A. Goldhammer. Philadelphia: University of Pennsylvania Press.

CHO HAEsuk 조해숙

2006 Paekche mokkan kirok "sukse kyŏrŏp” e tae hayŏ 백제 목간기로 “宿世結業” 에 대하여 [On the “sukse kyŏrŏp 宿世結業 . . .” inscribed on a Paekche mokkan]. Kwanak ŏmun yŏn'gu 관악어문연구 31:157-176.

CHO TONGIL 조동일

2005 Han'guk munhak t'ongsa 한국문학통사 [Complete History of Korean Literature], 5 vols. P'aju: Chisik Sanŏpsa.

FARris, William Wayne

1998 Sacred Texts and Buried Treasures: Issues in the Historical Archaeology of Ancient Japan. Honolulu: University of Hawai'i Press.

FRYDMAN, JOSHUA

2014. Uta mokkan: A History of Early Japanese Poetry through Inscription. Ph.D. diss. Yale University.

HONG KISǓNG 홍기승

2013 Kyŏngju Wŏlsŏng Haeja/Anapchi ch'ult'o Silla mokkan ŭi yŏn'gu tonghyang 경주 월성해자- 안압시 출토 신라목간의 연구 동향 [Trends in the research on the Silla mokkan unearthed at Wŏlsŏng moat and Anapchi in Kyŏngju]. Mokkan kwa muncha 목간과 문자 [Mokkan and Letters] 10:95-118.

HONG SǔNGU 홍승우

2013 Puyŏ chiyŏk ch'ult'o Paekche mokkan ŭi yŏn'gu hyŏnhwang kwa chŏnmang 扶餘지역 출토 백제 목간의 연구 현황과 전망 [Current state and future prospects for research on Paekche mokkan unearthed in the Puyŏ area]. Mokkan kwa muncha 목간과 문자 10:15-52.

KANG CHONGWǑN 姜鐘元

2009 Puyŏ Tongnam-ni wa Kŭmsan Paengnyŏng Sansŏng ch'ult'o muncha charyo 扶餘 東南里와 錦山 㮌嶺山城 出土文字史料 [Inscribed materials unearthed at Puyŏ Tongnam-ni and Kŭmsan Paengnyŏng fortress]. Mokkan kwa muncha 목간과 문자 3:245-261.

KI KYŎNGNYANG 기경량

2014 Puyŏ Kungnamji ch'ult'o mokkan ŭi saeroun p'andok kwa ihae 扶餘 宮南池 출토 목간의 새로운 판독과 이해 [A new decipherment and understanding of the mokkan unearthed at Kungnamji in Puyō]. Mokkan kwa muncha 목간과 문자 13:117-148.

KIM CHAEHONG 金在弘

2001 Puyŏ Kungnamji yujŏk ch'ult'o mokkan kwa kŭ ŭiŭi 扶餘宮南池遺蹟 出土木簡과 그의 意義 [The mokkan unearthed at the Puyŏ Kungnamji site and their significance], in Kungnamji II-hyŏn Kungnamji sŏbukp'yŏn iltae 宮南池 II - 現 宮南池 西北便一帶 - [Kungnamji II - northwestern zone of current Kungnamji]: 425-435, ed. Kungnip Puyŏ Munhwajae Yŏn'guso [Buyeo National Research Institute of Cultural Heritage]. Puyŏ: Kungnip Puyŏ Munhwajae Yŏn'guso.

KIM KYONYŎN 金教年

2005 Shiragi ōkyō to Shibi tojō ni tsuite 新羅王京と泗沘都 城について [About the Silla royal capital and the Sabi capital fortress], in Higashi Ajia ni okeru kodai toshi to kyūden 東アジアにお ける古代都市と宮殿 [Ancient cities and palaces in East Asia]: 99-109, ed. Nara Women’s University $21^{\text {st }}$ Century COE Program. Kodai Nihon keisei no tokushitsu kaimei no kenkyū kyōiku kyoten 古代日本形成の特質解明の研究教育拠点 [Basics for research education for analyzing the unique characteristics of the formation of ancient Japan], vol. 5. Nara: Nara Women's University $21^{\text {st }}$ Century COE Program.

KIM SŎNGBŎM 金聖範

2009 Naju Pogam-ni yujŏk ch'ult'o Paekche mokkan kwa kit'a muncha kwallyŏn yumul 羅州伏岩里 유적 출토 백제목간과 기타 문자 관련 유물 [The Paekche mokkan and other inscribed artifacts recovered from the Naju Pogam-ni site]. Mokkan kwa muncha 목간과 문자 3:217-253. 
2010 Naju Pogam-ni mokkan ŭi p'andok kwa sŏktok 羅州 伏岩里 木簡의 判讀과 釋讀 [Identification and interpretation of the Naju Pogam-ni mokkan]. Mokkan kwa muncha 목간과 문자 5:149-183.

KIM YŎNGSIM 김영심

2009 Puyŏ Nŭngsan-ni ch'ult'o ‘yukpu obang'mokkan kwa Paekche ŭi susulhak 扶餘陵山里 출토 “六队五方”목간과 백제의 数術學 [The 'yukpu obang 六队五方' mokkan unearthed from Puyŏ Nŭngsan-ni and Paekche numerology]. Mokkan kwa muncha 목간과 문자 3:127-148.

KIM YǑNGUK 金永旭

2003 Paekche idu e tae hayŏ 百濟 吏讀에 對하여 [On Paekche idu]. Kugyŏl yŏn'gu 口訣研究 11 (August):125-151.

Kondō KŌICHI 近藤浩一

2004 Puyŏ Nŭngsan-ni Nasŏng ch'ukcho mokkan ŭi yŏn'gu 扶餘陵山里羅城築造木簡의 研究 [Research on the mokkan from the construction of Nasŏng at Nŭngsan-ni, Puyŏ]. Paekche yon'gu 百濟研究 39:85-129.

2008 Puyŏ Nŭngsan-ni Nasŏng ch'ukcho mokkan chaeron 扶餘 陵山里 羅城築造木簡 再論 [A re-consideration of the Nasŏng construction mokkan from Puyŏ Nŭngsan-ni]. Hanguk kodaesa yŏn'gu 한국고대사연구 49(March):323-358.

Kungnip Puyŏ Pangmulgwan 국립부여박물관 [Buyeo National Museum]

2007 Nŭngsa: Puyŏ Nŭngsan-ni saji 6 8-ch'a palgul chosa pogosŏ 陵寺-부여능산리사지 6 8 차 발굴보고서- [Nŭngsa: Report on the 6-8th stages of excavations at the Puyŏ Nŭngsan-ni temple site, 2007]. Puyŏ: Kungnip Puyŏ Pangmulgwan.

Kungnip Puyŏ Pangmulgwan 국립부여박물관 [Buyeo National Museum] and Kungnip Kaya Munhwajae Yŏn'Guso 국립가야문화재연구소 [GAya National Research InSTITUTE Of Cultural Heritage]

2009 Namu sok amho mokkan 나무속 암호 목간 [History Passwords in Woods, Wooden Tablets]. Seoul: Yemaek.

KWŎN OYŎNG 권오영

2005 Kodae Tongasia munmyŏng kyoryu ŭi pit, Muryŏng Wangnŭng 고대 동아시아 문명 교류사의 빛, 무령왕릉 [The light of civilizational exchange in ancient East Asia, King Muryŏng's Tomb]. P'aju: Tolpegae.

Lee, SeungJae [see also Yi Sŭngjae]

2012 On the old Korean numerals inscribed on Wooden Tablet no. 318. Scripta 4(October): 28-68.

2013 A deciphering of two Silla poetry fragments inscribed on wooden tablets. Seoul Journal of Korean Studies 26(1):1-46.

2014 Old Korean writing on wooden tablets and its implications for old Japanese writing. Seoul Journal of Korean Studies 27(December):151-185.

2016 Developing a terminology for pre-hangeul Korean transcription. Scripta 8(October):25-71.

LuRIE, DAVID

2011 Realms of Literacy: Early Japan and the History of Writing. Cambridge, MA: Harvard University Asia Center.

Munhwajaech'Ŏng 文化財廳 [Cultural Heritage Administration] and Kungnip Kaya Munhwajae YǑn'GUSO 國立加耶文化財研究所 [GAYA National Research InStitute OF Cultural Heritage]

2011 Hanguk mokkan chajŏn 韓國木簡字典 [Character dictionary of Korean mokkan]. Ch'angwŏn: Kungnip Kaya Munhwajae Yŏn'guso.

PAK CHIHYŎN 박지현

$2015 a$ Kongsansŏng ch'ult'o muncha charyo 公山城 出土 文字史料 [Inscribed materials unearthed at Kongsan fortress], in Han'guk kodae muncha charyo yŏn'gu Paekche (sang) - chiyǒkpyŏl 한국 고 대 문자자료연구 백제(상)-지역별 -[Research on the inscribed materials from ancient Korea: Paekche (upper) - by region]: 29-39, ed. Kwŏn Inhan 권인한, Kim Kyŏngho 김경호, and Yun Sŏnt'ae 윤선 태. Han'guk mokkan hakhoe yŏn'gu ch'ongsŏ 1 한국목간학회 연구총서 01 [Korea Mokkan Society Research Series, vol. 1]. Seoul: Churyusŏng Ch'ulp'ansa.

2015 b Songsan-ni 6-hobun ch'ulto muncha charyo 宋山里 6 號墳 出土 文字史料 [Inscribed materials unearthed at Songsan-ni Tomb no. 6], in Hanguk kodae muncha charyo yŏn'gu Paekche (sang) - chiyǒk pyŏl 한국고대 문자자료연구 백제(상) - 지역별 -[Research on the Inscribed 
Materials from Ancient Korea: Paekche (Upper) - by Region]: 41-46, ed. Kwŏn Inhan 권인한, Kim Kyŏngho 김경호, and Yun Sŏnt'ae 윤선태. Hanguk mokkan hakhoe yŏn'gu ch'ongso 1 한국목간학회 연구총서 01 [Korea Mokkan Society Research Series, vol. 1]. Seoul: Churyusŏng Ch'ulp'ansa.

PAK Sunbal 박순발

2010 Paekche $\breve{u} i$ tosŏng 백제의 도성 [Capitals of Paekche]. Taejŏn: Ch'ungnam Taehakkyo Ch'ulpan Munhwawŏn.

SAKAEHARA TOWAO 栄原永遠男

2011 Man'yo uta mokkan wo ou 万葉歌木簡を追う [Chasing Uta Mokkan]. Osaka: Izumi Shoin. SIM SANGYUK 심상육 AND KIM YŎNGMUN 김영문

2015 Puyŏ Kua-ri 319 yujŏk ch'ult'o p'yŏnji mokkan ŭi ihae 부여 구아리 319 유적 출토 편지목간의 이해 [Understanding the letter mokkan unearthed at the Puyŏ Kuari 319 site]. Mokkan kwa muncha 목간과 문자 15:45-61.

SIM SANGYUK 심상육, YI MIHYŎN 이미현, AND YI HYOJUNG 이효중

2011 Puyŏ 'Chungang sŏnggyŏl kyohoe yujŏk' mit 'Twitkae yujŏk' ch'ult'o mokkan pogo 부여 '중앙성결교회유적' 및 '뒷개유적' 출토 목간 보고 [Report on the mokkan unearthed from Central Purity Church site and Twitkae site in Puyŏ]. Mokkan kwa muncha 목간과 문자 7:117-138.

SIM SANGYUK 심상육, YI MiHYŎN 이미현, AND YI MYŎNGHO 이명호

2012 Puy̆ Kua-ri 319 Puyŏ Chungang Sŏnggyŏl kyohoe yujŏk palgul chosa pogosŏ 부여 구아리 319 부여중앙성결교회 유적 발굴 조사 보고서 [Report on the excavation at the Puyŏ Central Holiness Church site at Puyŏ Kua-ri 319]. Puyŏ: Puyŏ-gun Munhwajae Pojon Sent'

SIN HǔIGWǑN 신희권

2014 Paekche ŭi muncha saenghwal kwa kwanjik, P'ungnap T’osŏng esŏ palgyŏn toen muncha wa puho 백제의 문자 생활과 관직, 풍납토성에서 발견된 문자와 부호 [Written life and bureaucracy in Paekche: Letters and symbols discovered at P'ungnap T'osŏng], in Kŭmsŏngmun ŭro Paekche rŭl ikta 금석문으로 백제를 읽다 [Reading Paekche through Epigraphy]: 11-38, ed. Pak Hyŏnju 박현주 and Cho Hyejin 조혜진. Seoul: Hagyŏn Munhwasa.

SON HwaniL 孫煥一

2010 Paekche mokkan ‘Chiyaga singmigi’ wa ‘chwagwan taesikki’ ŭi munch'e wa sŏch'e 百濟木簡 〈支薬兒食米記〉 와 〈佐官貸食記〉 의 文體와書體 [The sentence style and calligraphic style of the 'Chiyaga meal rice record' and 'Chwagwan lending meal record' Paekche mokkan]. Sillasa hakpo 신라사학보 18(April):231-266.

Tsien, TSUEN-Hsuin.

[1962] Written on Bamboo and Silk: The Beginnings of Chinese Books \& Inscriptions. Chicago: University

2004 of Chicago Press.

WATANABE AKIHIRO 渡辺晃宏

2014 Mokkan wo horu - shiryō to shite no mokkan, mokkan no shutsudo to seiri 木簡を掘る 一資 料としての木簡、木簡の出土と整理 [Digging up mokkan: Mokkan as research material, unearthing and sorting mokkan], in Rekishi no shōnin: mokkan wo kiwameru 〈歴史の証人〉木簡 を究める [Witnesses of History: Researching Mokkan]: 9-42, ed. Nara Bunkazai Kenkyujo [Nara National Institute for Cultural Properties]. Tokyo: Kuba Pro.

YI CHAECH'ŎL 이재철

$2015 a$ Kŭmsan Paengnyŏng Sansŏng ch'ulto muncha charyo 錦山 㮌嶺山城 出土 文字資料 [Inscribed materials from Paengnyŏng fortress in Kŭmsan], in Han'guk kodae muncha charyo yŏn'gu Paekche (sang) - chiyǒkpyŏl 한국고대 문자자료연구 백제(상)-지역별 -[Research on the inscribed materials from ancient Korea: Paekche (upper) - by region]: 427-455, ed. Kwŏn Inhan 권인한, Kim Kyŏngho 김경호, and Yun Sŏnt'ae 윤선태. Han'guk mokkan hakhoe yŏn'gu ch'ongsŏ 1 한국목간학회 연구총서 01 [Korea Mokkan Society Research Series, vol. 1]. Seoul: Churyusŏng Ch'ulp'ansa.

$2015 b$ Naju Pogam-ni yujŏk ch'ult'o muncha charyo 羅州 伏岩里 遺蹟 出土 文字資料 [Inscribed materials from the Pogam-ni site in Naju], in Hanguk kodae muncha charyo yŏn'gu Paekche (sang)chiyókpyol 한국고대 문자자료연구 백제(상)-지역별 -[Research on the inscribed materials from ancient Korea: Paekche (upper) - by region]: 457-502, ed. Kwŏn Inhan 권 인한, Kim Kyŏngho 김경호, and Yun Sŏnt'ae 윤선태. Han'guk mokkan hakhoe yŏn'gu ch'ongsŏ 1 한국목간학회 연구총서 01 [Korea Mokkan Society Research Series, vol. 1]. Seoul: Churyusŏng Ch'ulp'ansa. 
YI CHAEHWAN 이재환

2014 Puyŏ Nŭngsan-ni saji yujŏk ch'ult'o mokkan mit saksŏl 扶餘 陵山里寺址 유적 출토 목간 및 삭설 [The mokkan and wooden shavings unearthed at the Nŭngsan-ni temple site in Puyŏ]. Mokkan kwa muncha 목간과 문자 12:121-174.

2015 Muryŏng Wangnŭng ch'ulto muncha charyo 武寧王陵 出土 文字資料 [Inscribed materials from the tomb of King Muryŏng], in Han'guk kodae muncha charyo yŏn'gu Paekche (sang) chiyŏkpyŏl 한국고대 문자자료연구 백제(상) - 지역별 -[Research on the inscribed materials from ancient Korea: Paekche (upper) - by region]: 47-68, ed. Kwŏn Inhan 권인한, Kim Kyŏngho 김경호, and Yun Sŏnt'ae 윤선태. Han'guk mokkan hakhoe yŏn'gu ch'ongsŏ 1 한국목간학회 연구총서 01 [Korea Mokkan Society Research Series, vol. 1]. Seoul: Churyusŏng Ch'ulp'ansa.

YI KYŎNGSŎP 이경섭

2013 Silla mokkan ŭi segye 신라 목간의 세계 [The World of Silla Mokkan]. Seoul: Kyŏngin Munhwasa.

YI PYŎNGHO 李炳鎬

2008 Puyŏ Nŭngsan-ni ch'ult'o mokkan ŭi sŏnggyŏk 扶餘 陵山里 出土 木簡의 性格 [Characteristics of the mokkan unearthed at Puyŏ Nŭngsan-ni]. Mokkan kwa muncha 목간과 문자 1:49-91.

2013 Paekche Sabi sigi tosŏng ŭi ŭirye konggan kwa wanggwŏn - t'onghap chungch'u rosoŭu wanggung kwa sawŏn ŭl chungsim ŭro 百濟 泗沘時期 都城의 儀禮 空間과 王權 -統合中 樞로서의 王宮과 寺院을 중심으로 [Ceremonial space and the throne in the Paekche Sabi period capital-fortress: With a focus on the royal palace and temple complexes as integrated centers]. Han'guk kodaesa yŏn'gu 한국고대사연 구 71:97-136.

Yi SǔngJAE 李丞宰 [see also LeE, SEUNGJAe]

2008295 pŏn kwa 305 pŏn mokkan e tae han kwan'gyŏn 295번과 305 번 木簡에 대한 管見 [My point of view on Mokkan No. 295 and Mokkan No. 305]. Paekche mokkan: sojangp'um chosa charyojip 백제목간-소장품조사자료집 [Paekche Mokkan: Resources Based on the Study of the Collection]. Puyŏ: Kungnip Puyŏ Pangmulgwan.

2017 Mokkan e kirok toen kodae han'gugŏ 木簡에 기록된 古代 韓國語 [The Old Korean Language Inscribed on Wooden Tablets]. Seoul: Ilchogak.

YI YONGHYŎN 이용현

2007 Mokkan 목간, in Paekche ŭi muncha wa saenghwal 백제의 문화와 생활 [Life and culture in Paekche]: 265-298, ed. Ch'ungch'ŏngnam-do Yŏksa Munhwa Yŏn'guwŏn. Paekche munhwasa taegye [Paekche Cultural History Series], vol. 12. Kongju: Ch'ungch’ŏngnam-do Yŏksa Munhwa Yŏn'guwŏn.

2013 Naju Pogam-ni mokkan yŏn'gu hyŏnhwang kwa chŏnmang 나주 복암리 목간 연구 현황과 전망 [Current state of and prospects for research on the Naju Pogam-ni mokkan]. Mokkan kwa muncha 목간과 문자 10:53-75.

YUN SŎNT’AE 尹善泰

2007a Mokkan i tŭllyŏ chunŭn Paekche iyagi 목간이 들려주는 백제 이야기 [Paekche Stories told by Mokkan]. Seoul: Churyusŏng Ch'ulp'ansa.

2007 b Mokkan kara mita Kudara Shibi tojō no uchi to soto 木簡 からみた百済泗沘都城の内と外 [The interior and exterior of Paekche's Sabi capital as seen through mokkan], trans. Pak Min'gyŏng 朴珉慶, in Kankoku shutsudo mokkan no sekai 韓国出土木簡の世界 [The World of Mokkan Unearthed from Korea]. Chōsen Bunka Kenkyūjo 朝鮮文化研究所. Ajia chiiki bunkagaku sōsho アジア地域文化学叢書 [Asian Region Cultural Studies Series], vol. 4. Tokyo: Yuzankaku. 